\title{
Miranda
}

Revue pluridisciplinaire du monde anglophone /

Multidisciplinary peer-reviewed journal on the English-

speaking world

5 | 2011

South and Race / Staging Mobility in the United States

\section{Re-Writing Race in Early American New Orleans}

\section{Nathalie Dessens}

\section{OpenEdition}

\section{Journals}

Electronic version

URL: http://journals.openedition.org/miranda/2296

DOI: 10.4000/miranda.2296

ISSN: 2108-6559

\section{Publisher}

Université Toulouse - Jean Jaurès

\section{Electronic reference}

Nathalie Dessens, "Re-Writing Race in Early American New Orleans", Miranda [Online], 5 | 2011, Online since 29 November 2011, connection on 16 February 2021. URL: http://journals.openedition.org/ miranda/2296 ; DOI: https://doi.org/10.4000/miranda.2296

\section{This text was automatically generated on 16 February 2021.}

\section{$\Theta \Theta \Theta$}

Miranda is licensed under a Creative Commons Attribution-NonCommercial-NoDerivatives 4.0 International License. 


\title{
Re-Writing Race in Early American New Orleans
}

\author{
Nathalie Dessens
}

1 Louisiana's first century of history accounts both for its inclusion in the antebellum American South and for the specificities it displayed in the young American republic. After six decades of French rule, it became a Spanish colony at the end of the Seven Years' War, before briefly-and secretly-returning to French rule, in 1800, and being eventually sold, in 1803, to the United States by France. Its colonial past made it a slave colony, like the rest of the Anglo-American South, but it also made its social order slightly different from the rest of the South. Its three-tiered order, although it was by no means an exception in the plantation societies of the North-American continent, contradicted the biracial order that prevailed in most of the South and in the psyche of the new American rulers of Louisiana in the early nineteen ${ }^{\text {th }}$ century.

When Louisiana was turned over to the United States, many historians contend, the old Creole population ${ }^{1}$ and the new rulers of Louisiana started conflicting over how to legislate on the racial order and how to deal with race relations in this new territory (then state) of the Union. Until relatively recently, the Creole/American opposition has been set forth by historians of Louisiana as the backbone of racial representations in early American Louisiana. ${ }^{2}$

Recent historiography, however, has tended to show that, if this binary opposition is often a correct representation of the debates over racial questions in early American Louisiana, it is most certainly an oversimplification and cannot account for all the representations of race relations in Louisiana in the first four decades of American rule. This article is a contribution to these new historiographical trends.

4 Relying on a specific testimony, that of Jean Boze, a Frenchman arrived in New Orleans with the large wave of refugees from the French Caribbean colony of Saint-Domingue at the time of the Haitian Revolution, this article contends that the pattern of race interactions and race relations was much more complex than that defined by the Creole/American opposition. It will first examine the history and historiography of race relations in colonial and early American Louisiana, before examining the way in 
which testimonies of residents of Louisiana in the early national period may help revisiting the writing of race in the early postcolonial Crescent City.

\section{Races in context in colonial New Orleans}

5 The first period of French rule over Louisiana (1699-1763) clearly placed Lower Louisiana among the slave societies of the North-American continent. ${ }^{3}$ When Spain took over, in 1763 , Louisiana already had a slave population of 4,598 that slightly outnumbered its free population (only 3,654). ${ }^{4}$ Although the late French colonial period was marked by a slowing down of slave importations, ${ }^{5}$ the almost forty years of Spanish rule clearly confirmed Louisiana's place among the main slave societies of NorthAmerica. ${ }^{6}$ By 1800 , when Louisiana was retroceded to France by Spain through the Treaty of San Ildefonso, the slave population of Lower Louisiana amounted to 24,264, again outnumbering the free population $(19,852) .^{7}$ Lower Louisiana was thus ready to integrate the Anglo-American slave South, which it did as territory in 1803, and as state in 1812. Before the debate over the integration of Missouri into the Union started, Louisiana had quietly become one of its main slave states.

6 Throughout its colonial period, and in parallel with the progressive expansion of the institution of slavery, Louisiana witnessed the development of a perfectly codified three-tier order. As was the rule in the French and Spanish colonies of the Caribbean, a free population of color developed and expanded alongside free whites and enslaved blacks, especially under Spanish domination. Because Spanish codification gave the slaves the possibility to purchase their own freedom (coartación), and because it was current practice for white fathers in French and Spanish colonies to free their raciallymixed children, the free population of color increased steadily, albeit slowly, in the four decades of Spanish rule. ${ }^{8}$ In New Orleans alone, their number grew from 97 in 1771 (3.1\% of the total population, $5.1 \%$ of the free population, $7.3 \%$ of the nonwhite population) to 1,566 in 1805 (19\% of the total population, 30.6\% of the free population, $33.5 \%$ of the nonwhite population). ${ }^{9}$

7 The free population of color, mainly-but not solely-present in New Orleans, had acquired, by the late Spanish colonial period, a number of privileges and had made its place in the socioeconomic order..$^{10}$ In the past three decades, many historians of Louisiana have commented on this characteristic of colonial Louisiana. Although several Anglo-American Upper-South states or urban areas (like Charleston) also had free populations of color, historians have systematically proclaimed their socioeconomic and cultural role a specific feature of Louisiana. Speaking of New Orleans, Kimberly Hanger, for instance, writes that "over time there emerged in New Orleans what might be considered a free black 'elite,' although not on the scale of the gens de couleur of Saint-Domingue in the same period or of the large free property holders that made Louisiana distinctive in the antebellum United States" (Hanger 55). They owned, bought, and sold property according to a geographical pattern that denoted no residential segregation (Hanger 138). ${ }^{11}$ Beyond freedom and property rights, the free people of color had privileges unheard of in other urban societies of the American South. Belonging to the militia was one of them, in keeping with the French and Spanish Caribbean traditions, and it gave a sense of "corporate identity" to the free people of color of the Louisiana capital and granted them several distinctive privileges not found in the rest of the South (Hanger 109). ${ }^{12}$ In the late colonial period, Louisiana 
was a slave society, based on a three-tiered order, not unlike the other Spanish or French colonies of the Americas.

When the Americans took over, in 1803, after three brief years of secret French rule, the territory they incorporated was clearly singular. Although other slave regions of the United States had free populations of color endowed with certain privileges, Louisiana was where the free people of color enjoyed the most rights, including that of serving in the militia and all the privileges attached to the function. They sometimes held much property and had a certain power of negotiation with the white authorities (Hanger 136-162).

\section{Races in context in early American Louisiana}

9 Although Anglo-Americans had started migrating to Louisiana a decade before the young American republic purchased the territory, the influx became an uninterrupted flow after the Purchase. The new status of Louisiana triggered several changes in the racial distribution of the inhabitants of Lower Louisiana. The first obvious demographical consequence of the Louisiana Purchase was the relative proportional decrease of the free population of color, the in-migration from the eastern United States including mostly white people and slaves. The second was an immediate attempt by the Americans at reorganizing the territory according to their standards, in terms of government but also of social and racial organization. This resulted in a reconfiguration of the role of the free blacks in New Orleans society. They "encountered increasing discrimination and legal restrictions that would draw them together and more clearly define their position in New Orleans society" (Hanger 163). They remained, however, a substantially powerful group in the Louisiana society. Their property holding went on increasing, ${ }^{13}$ they went on interacting with the white population, and retained their distinct status in New Orleans until the Civil War. Their presence in the militia was not even threatened, despite a relative loss of prestige of the function (Hanger 134).

10 For a very long time, historians avoided addressing this specificity and assumed that there was no need to singularize early American Louisiana from the rest of the slave South in terms of races and race relations. ${ }^{14}$ For decades after the Civil War, American historians discussed race in the South in general, without focusing on regional differences. New Orleans historians were scarce and had difficulty gaining national recognition. Most of the historians were strangers to the Crescent City and a Louisiana exception was no part of the canonical American narrative ${ }^{15}$ which was more intent on pitting against each other the main sections interacting in the antebellum era than on showing the complexity and heterogeneousness of the individual sections. In the second half of the twentie ${ }^{\text {th }}$ century, dissenting voices arose, mostly in New Orleans but also in the rest of the country, and the historiography of Louisiana started revising this depiction of a uniform, homogeneous antebellum South. ${ }^{16}$ Since then, historians have taken pains to show that New Orleans had a racial organization and a pattern of race relations that greatly differed from the rest of the South. ${ }^{17}$ They have highlighted the existence of the three-tiered order, common with the Latin colonies of the Caribbean, and inherited from the French and Spanish colonial era. Although many have focused on how the system became increasingly fixed when the Americans took over Louisiana and how the Creoles attempted to counter this American influence, most historians 
have also concluded that "the long contest between the creoles and the Americans proved a major force in shaping the unusual character of New Orleans" (Hirsh and Logsdon 91).

11 What mostly comes out of these reinterpretations of Louisiana's early postcolonial history is the opposition between Creoles and Americans in the management of racial statuses and race relations..$^{18}$ Through the prism of the struggle for power between the Creole population and the new American rulers, they show the complexity of race relations in rapidly changing Louisiana. The vision that has emerged from these reinterpretations of Louisiana's early postcolonial history is one of a slightly isolated Louisiana, still extremely Latin in its management of race relations, despite the attempts of the new American rulers to impose their more binary conception. In the early national period, New Orleans remained, as historians have shown, a three-tiered order, with a relatively more relaxed management of interracial relations, where free people of color often thrived and managed to keep an intermediate position which deprived them of any political power but gave them space for economic and cultural influence. Although this representation of race relations in New Orleans is much closer to historical reality than the earlier ones, history never stops reinterpreting the past and recent historiographical trends have started elaborating more dialectic depictions of the racial order and giving a much more complex vision of race relations in early postcolonial New Orleans. ${ }^{19}$ This more dialectic conception is doubtlessly still a better representation of race relations in early postcolonial New Orleans.

The management of races and race relations, in particular, is indeed much more complex than what was hitherto believed, first of all, because historians have started reassessing the complexity of the Louisiana fabric in the early postcolonial period. If the confrontation between Creoles and Americans was one of Louisiana's main constitutive elements in the first decades of the nineteen ${ }^{\text {th }}$ century, there were several in-migrations that made the confrontation anything but binary. Those years were an era of tremendous growth for the city, which went from a population of about 8,000 inhabitants in 1803 to being the third largest city in the United States in 1840, with a population of 102,193 inhabitants (Dessens 2011, 108). This tremendous increase had several origins: the constant influx of foreigners, from Europe for the most part (from France, Germany, Ireland, principally), but also from Mexico at the time of the independence from Spain in 1821; and the tremendous influx of Saint-Domingue refugees.

In several waves, between 1791 and 1810, about 15,000 Saint-Domingue refugees came to Louisiana (mostly New Orleans), more or less equally distributed into whites, blacks, and free people of color. This influx was essential in inflecting the racial policies in early American Louisiana. The arrival of the refugees, first of all, numerically reinforced the free population of color whose proportion to the total population had started diminishing owing to the influx of the Anglo-Americans who had brought numerical additions to the white and slave groups almost exclusively. When the last wave of refugees came to New Orleans from Cuba, in 1809-1810, this influx more than doubled the free population of color, which immediately went up by $134 \%$ (Dessens 2007, 27). Mentioning this influx, Hanger concludes on "the dramatic increase in their numbers and cultural influence" it brought to the free people of color (Hanger 163).

New Orleans thus had, in the early nineteen ${ }^{\text {th }}$ century, a very diverse population, ethnically heterogeneous. It is clear that the perception of race relations could not be 
the same for all the ethnic groups. ${ }^{20}$ Much has been written in recent decades about the Anglo-Americans and their biracial pattern. There was, however, more diversity than heretofore believed since, among the new inhabitants of Louisiana, were also people who came from countries that had never relied on slavery (like Germany) or from countries that had institutionalized slavery in their colonies (like Spain). Much is also known about the Creole vision based on the three-tiered order of society, inherited from the French and Spanish colonial era. The French-speaking group was much more heterogeneous than what was long thought, since new migrants ceaselessly arrived, either from French American slave colonies (like Saint-Domingue) or from metropolitan France. It may be inferred that there was thus no single perception of races and race relations in this very composite population.

It is thus important, in the early twenty-first century, to try to reassess the relationships between the various racial groups-enslaved blacks, free people of color, and whites-in the context of this important ethnic diversity. Primary sources indicate that Louisiana's racial and ethnic pattern was so rich that each group had its own discourse on race and race relations and that there could even be diversity within each ethnic group. There was not one single way of writing race in the Crescent City in Louisiana's early national era and it is important to try to reconstruct this complex pattern by using new, relatively unexplored testimonies written by Louisianans at the time. An insight into the Saint-Domingue refugee group, for instance, attests to this rich diversity.

\section{A Saint-Domingue refugee's testimony}

Among the many rich sources that give insights into the complexity of the system, is a long correspondence written by Jean Boze to Henri de Ste-Gême, archived at The Historic New Orleans Collection. ${ }^{21}$ The Ste-Gême Family Papers (MSS 100) contain, among many other items, 158 letters written by Jean Boze between 1818 and 1839, covering 1150 pages, which give precious insight into the pattern of race relations in early postcolonial New Orleans.

Jean Boze was a Frenchman born in 1753 near Marseilles..$^{22}$ Originally a captain in the French merchant marine, he had settled in Saint-Domingue, the French colony that is today Haiti, in the early 1780s. Married to a white Creole whose family had settled in the colony three generations before and possessed several coffee plantations, he was successively the captain of the harbor of Jacmel, a royal notary in Ste. Lucie (now St. Lucia), a Corsair for the Dutch in Curacao, a merchant in Saint-Domingue, and the captain of the harbor of Port Républicain (the name of Port-au-Prince at the time). Evacuated from Saint-Domingue in the last days of the Haitian Revolution, in late 1803, he lost his wife in their last moments on the island, and found refuge in Santiago de Cuba, in the Cuban Oriente, with his two children. In 1809, he had to flee with some 10,000 other Saint-Domingue refugees, when the Cuban colonial authorities expelled the French citizens, in response to Napoleon's European policies (Dessens 2010, "Napoleon," 69). He then found his second asylum, New Orleans.

He fled with Henri de Ste-Gême, a nobleman from southwestern France, a high-ranking officer in the French army, who had fought the Haitian Revolution under various flags, had been discharged for health reasons, and had also settled in Santiago de Cuba in August 1803. On their way to New Orleans, if not before, they became close. Since Boze 
was carried to New Orleans on one of Ste-Gême's ships, and with him, they probably already knew each other. In New Orleans, Ste-Gême married a Louisiana Creole who had inherited a plantation in Gentilly, a few leagues from the city center, from her deceased husband. He then returned to his French country castle, the cradle of his family, near Toulouse, in 1818. He trusted Jean Boze so much that he left all his financial assets and his illegitimate family of color in his care. He had indeed come to New Orleans with his companion of color from Saint-Domingue, with whom he had had three children, all born in New Orleans, and thus Creoles of color of New Orleans. After Ste-Gême's departure, and apparently at his request, Boze wrote him letters that he often calls "newsletters", and that mostly resemble a log book, in keeping with their author's original training as a ship captain.

19 In his letters, for twenty years, Boze recounted life in New Orleans for Ste-Gême. His thorough reports, aimed at keeping Ste-Gême informed about all the evolutions of the city in the eventuality of his return to New Orleans (which never occurred), described the social, economic, political, and cultural changes that the city was undergoing in those extremely lively twenty years of the early postcolonial era. ${ }^{23}$

All of the letters contain insightful information on race relations in New Orleans at that time. Boze's position is an original one. As part of the Saint-Domingue refugee group, he writes both as an insider and an outsider to the system. He is, to some degree, an insider, in that he had been living in American colonies for almost four decades when the correspondence started. Having lived in French and Spanish Caribbean colonies, he intimately knew the slave colonies of the Latin European countries. Although he had not been a slave owner personally, his wife's family had had large coffee plantations in Saint-Domingue. As a harbor captain and as a ship captain involved in corsair activities, he had, at least indirectly, condoned the institution of slavery. He was, however, also an outsider to Louisiana, having settled there six years after its purchase by the United States, and only three years before statehood. He was no part of the Louisiana Creole society, although he obviously had connections with it. As part of the Saint-Domingue refugee group, he observed from a distance the struggle for power between the Americans and the Creoles. As an already old man who had no direct involvement in the economic and political life of his new home, he had a relatively detached and impassionate perspective. This makes for the richness and interest of his testimony.

\section{Ethnicity, origins, and the writing of race}

Boze had a complex relationship to race. Although he had never owned slaves himself, he had lived in close contact with slavery and had married the daughter of a slaveholding family. He had had to flee Saint-Domingue just before it became the Republic of Haiti and had lost his wife, killed by the black insurgents. All in all, he spent 60 of his 90 years in slave societies. But he also took good care of Ste-Gême's family of color. And what his letters show is a strange mixture of racial prejudice, general agreement with the New Orleans fixed racial order, and a clear tendency to often let other considerations supersede his perception of races. His letters show a permanent wavering between his belief in the whites' superiority, his defense of the three-tiered order and opposition to any attempt at reducing this order to any binary perception of races, and the strong sense of belonging he had developed in the St. Domingue refugee group. 
Boze never questions the legitimacy of slavery. For him, it was a normal feature of society, in keeping with his past and present life. Whenever he mentions slaves, he does it as someone who has integrated the institution in his mental representation of society. When he reports the condemnation of a mulatto slave for killing a white, he says it is "a loss for the owner" and adds that "this master still has the weakness of saying he was a good subject" and of wanting to save him..$^{24}$ Informing Ste-Gême of the death of one of his slaves, who had been weak and sick for some time, he adds "it is a new loss for you, which will prove the qualities of your heart since you could have sold him" (F 23, 10/08/18). He-often implicitly, but also sometimes explicitly-condones slavery, including the enslavement of racially mixed persons. Whenever he seems to criticize the system, he is, in fact, only condemning unusual cruelty. He denounces the "cruel nature" of Widow Lanusse towards her slaves and Widow Blanque's "barbarous treatment" of hers (F 134, 01/12/28). Beside cruel treatment, the only thing that apparently made him cringe was the constant importation of slaves from the AngloAmerican states, and he recurrently expresses the opinion that these bad subjects jeopardize public peace and may trigger revolts. In 1831, he expatiates on the two great slave rebellions of Jamaica (the Christmas rebellion) and South Carolina (Nat Turner's rebellion) and keeps commenting that this is what will happen in Louisiana if the constant influx of Anglo-American slaves does not stop:

I will not tell you about those who have already arrived, but will only mention that, for the past two years, over 20,000 slave nègres ${ }^{25}$ of both sexes and of all ages have been introduced, vomited here by the northern places, as much for the lure of profit as to get rid of that caste.

23 He concludes that motions have been introduced in the legislature to end "this dangerous practice" (F 175, 22/11/30-23/01/31). In short, slavery is normal, whether the slaves are nègres or mulâtres, which corresponds to the vision shared by the population of New Orleans in general. If anything needs to be criticized, it is the increasing proportion of slaves from the Anglo-American South in the Louisiana slave population.

Boze also seems to readily side with the existence of a relatively stratified three-tiered order. He regularly mentions the free people of color, informs Ste-Gême on the group without ever being judgmental about their economic weight, shows that they were involved in the social order, and even that, in New Orleans, they shared practices normally reserved for whites in the rest of the South. New Orleans Creoles of color, including those with Saint-Domingue origins, were, for instance, regularly involved in dueling, a practice normally reserved for gentlemen in the rest of the South. ${ }^{26}$ Naturally, Boze's mission to take care of Ste-Gême's illegitimate children was fulfilled scrupulously and he expresses both admiration and affection for the three children. They were the owners of their house and six slaves, were given a good education, including the teaching of English to the young son, Gême, to prepare his future in an increasingly Anglophone Louisiana; the girls learned sewing, the boy was being trained as a joiner and cabinetmaker; they also benefited from the renting of part of their house and slaves. He adds, several times, that "they mingle with the best society of their color" (F 231, 11/08-26/09/33), which suggests, beyond the close proximity he has with them, his general acceptance of a separate racial order. But he is never judgmental about interracial relations, informing Ste-Gême about them as part of the social order. To give a single instance, he tells him, without passing the least judgment, about Mr. Delegue, the former business partner of Prudent Casamajor, who had married his 
"housekeeper", the sister of Casamajor's "housekeeper", ${ }^{27}$ in Santiago de Cuba "to make his natural children inherit" (F 189, 20/08-20/11/31). This is in keeping with what historians have recently written about the attitude of New Orleans Creoles towards the three-tiered order and interracial relationships that prevailed in the city and clearly indicates a certain homogeneousness among the French speakers, whatever their origins.

What is more unusual and less in keeping with the traditional depictions of the pattern of race relations is that Boze is also ready to let group solidarity supersede the strict racial order of Louisiana's society. Indeed, very often, from what he writes and from the wording he uses, the cultural and ethnic origins of the people he mentions seem more important than their color. What he despises most is not slaves, but slaves from the English-speaking United States. Already more acceptable are the black Creoles, be they slaves or free people of color. But the group he is most defensive of is obviously that with Saint-Domingue origins. And his solidarity goes to the refugee group, whatever the color of the people he mentions. He always speaks nicely of slaves brought over from Saint-Domingue by their refugee masters and he never suggests that they may jeopardize the Louisiana peace and order. He is always ready to support the free people of color in their response to any attempt at limiting their rights. Most of the news he gives concern Saint-Domingue refugees, whatever their color and, whereas he rarely mentions Anglo-Americans in the information he gives to Ste-Gême, he writes at length about the refugees, mostly whites and free people of color, which shows that people tended to get acquainted with members of their ethnic group in this early postcolonial era. The various groups apparently mingled as little as they could across the language barriers, while Louisiana Creoles and Saint-Domingue refugees seem to have interacted more easily and while there seems to have been much interaction between whites and free people of color within the Saint-Domingue refugee group. ${ }^{28}$

Boze also constantly criticizes any attempt on the part of the state or city authorities to legislate against the free people of color, as when Francophone Senator Antoine Ducros, in May 1834, introduced a bill setting a fine for any teacher teaching free people of color, children or adults, to read and write. He concludes that the bill has fortunately been rejected and that this group will continue to have "the liberty to get for themselves and their family the education they want" (F 239, 04/05-06/06/34). This example shows not only that Boze was protective of the free people of color but also that, contrary to what is often believed about early American Louisiana, the Anglophones were not the only ones trying to pass legislation limiting the rights and prerogatives of the free people of color. Boze sometimes even mentions specifically the Saint-Domingue Creoles of color in his criticism against the restrictive legislative attempts, as when, in January 1830, the legislature tried to pass a law preventing free people of color from settling in Louisiana, section 12 of the act requiring all free people of color who had entered the state between the adoption of the 1812 Constitution and 1 January 1825, to register with the judge of their parish or with the Mayor's Office if they lived in New Orleans. Although most of the free refugees of color had been in New Orleans before 1812, he feared for them and concludes:

we hope there will be a change, to avoid pushing to despair unfortunate families who have been refugees for 23 years, on the belief that this was a free country which had welcomed them with open arms, and to whose laws they have submitted and which they have religiously abided by until now. (F 157, 25/01-19/02/30) 

Louisiana. In another letter, he praises the bravery of a free refugee of color, Major Savary, who was the first black officer in the US army during the Battle of New Orleans, ${ }^{29}$ and shows how it favorably compares to that of a white combatant, General Lacoste. Commenting on the honors given, upon his death, to Lacoste, who had commanded the Company of the Louisiana free people of color, he minimizes Lacoste's courage and puts forward the superiority of Savary, concluding:

I must not forget, on this occasion, to say a few words on the bravery of the late Savary Jr., who commanded the company of the free people of color from SaintDomingue, and who, with this company, fought the enemy with an astonishing dauntlessness, deserving, upon his death, a truthful necrology on his behavior and his courage in war (F 242, 15-18/07/34).

28

Many of his remarks, just like this one, seem to be color-blind, as long as the person he mentions is a Saint-Domingue peer. This solidarity is not reserved to Boze and was clearly the practice of the refugee community. When Ste-Gême's older illegitimate daughter married, for instance, she had a marriage contract drawn, and a white notary from Saint-Domingue, Marc Lafitte, had "the good heart of serving as counsel to that orphaned family" ${ }^{30}$ (F 216, 12/01-08/02/33), proving that most white refugees were often ready to protect and assist the free refugees of color.

In short, the most important element in Boze's identity is the sense of community he shares with the people who have experienced exile (sometimes double exile) from Saint-Domingue to New Orleans. ${ }^{31}$ And he shows that this solidarity is strong among the Saint-Domingue refugees, with a high degree of color blindness that has not yet been highlighted by historians. This sense of community blurs racial boundaries, makes color lines more flexible, and suggests that there were many different ways of perceiving and writing race in early postcolonial New Orleans.

Recent historical literature has tended to restore, step by step, the complexity of race relations in early postcolonial New Orleans. Historians have shown that race relations were probably more complex in New Orleans than anywhere else in the United States due to the specific colonial history of the city and to its highly cosmopolitan character in the early colonial period.

31 Creoles and Americans differed in their conceptions of race relations and this difference is attested by legislation and legislative attempts, although Jennifer Spear has recently shown that, if changes in the ownership of Louisiana were followed by legislative modifications, the practice of race relations between the French, Spanish, and American periods displayed more continuity than what is commonly believed.

Boze's testimony may be considered as anecdotal in the larger Louisiana picture, and to a large extent, it is. Its interest is to show, from inside, that it is impossible to generalize when trying to write the history of races and race relations in Louisiana in the early national era. All French speakers did not think alike and all Anglo-Saxons did not necessarily think alike either. Boze's example also shows that historians still have much to discover in the many testimonies left behind by the inhabitants of the Crescent City. The ethnic and racial fabric of New Orleans was so heterogeneous in terms of national and cultural origins that a better focus on the interplay between race and ethnicity is necessary before historians manage to honor the richness of the Crescent City's society at that time. 


\section{BIBLIOGRAPHY}

Berlin, Ira. Many Thousands Gone. The First Two Centuries of Slavery in North America. Cambridge, Massachusetts, and London, England: The Belknap Press of Harvard University Press, 1998.

---. Generations of Captivity. A History of African American Slaves. Cambridge, Massachusetts, and London, England: The Belknap Press of Harvard University Press, 2003.

Cossé-Bell, Caryn. Revolution, Romanticism, and the Afro-Creole Protest Tradition in Louisiana 1718-1868. Baton Rouge: Louisiana State University Press, 1997.

Dessens, Nathalie. From Saint-Domingue to New Orleans: Migration and Influences. Gainesville: University Press of Florida, 2007.

---. "Louisiane, terre d'aventure". Sources 20-21 (automne 2008): 138-149.

---. "Napoleon and Louisiana: New Atlantic Perspectives." Napoleon's Atlantic: The Impact of Napoleonic Empire in the Atlantic World. Eds. Christophe Belaubre, Jordana Dym and John Savage. Leiden and Boston: Brill, 2010. 63-77.

---. "La Nouvelle-Orléans au XIXe siècle : femmes de couleur libres, femmes de pouvoir ?". Anglophonia 27 (2010): 107-118.

---. "New Orleans" in "Cities in the Early Republic, 1790-1828." In Cities in American Political History. Ed. Richardson Dilworth. Los Angeles, London, New Delhi, Singapore, Washington DC: Sage, CQ Press, 2011. 103-108.

Domínguez, Virginia. White by Definition. Social Stratification in Creole Louisiana. New Brunswick, New Jersey and London: Rutgers University Press, 1997.

Fossier, Albert E. New Orleans. The Glamour Period, 1800-1840. 1957. Gretna: Pelican Publishing Company, 1998.

Hall, Gwendolyn Middlo. Africans in Colonial Louisiana. The Development of Afro-Creole Culture in the eighteenth century. Baton Rouge: Louisiana State University Press, 1992.

Hanger, Kimberly S. Bounded Lives, Bounded Places. Free Black Society in Colonial New Orleans, 1769-1803. Durham and London: Duke University Press, 1997.

Hirsh, Arnold and Joseph Logsdon. Creole New Orleans. Race and Americanization. Baton Rouge: Louisiana State University, 1992.

Ingersoll, Thomas. Mammon and Manon in Early New Orleans. The First Slave Society in the Deep South, 1718-1819. Knoxville: University of Tennessee Press, 1999.

Kastor, Peter J. and François Weil, eds. Empires of the Imagination. Transatlantic Histories of the Louisiana Purchase. Charlottesville and London: University of Virginia Press, 2009.

Lachance, Paul. "The Formation of a Three-Caste Society: Evidence from Will in Antebellum New Orleans." Social Science History 18:2 (Summer 1994): 211-242.

Phillips, Ulrich. American Negro Slavery. New York: D. Appelton and Company, 1918.

Remini, Robert V. The Battle of New Orleans. Andrew Jackson and America's First Military Victory. New York: Penguin, 1999.

Sainte-Gême's Family Papers, MSS 100, The Historic New Orleans Collection, New Orleans, Louisiana. 
Scott, Rebecca. "Public Rights and Private Commerce. A Nineteenth-Century Atlantic Creole Itinerary." Current Anthropology 48:2 (April 2007): 237-256.

Spear, Jennifer M. Race, Sex, and Social Order in Early New Orleans. Baltimore: The Johns Hopkins University Press, 2009.

Stampp, Kenneth. The Peculiar Institution: Slavery in the Ante-Bellum South. New York: Alfred A. Knopf, 1956.

Sublette, Ned. The World That Made New Orleans. From Spanish Silver to Congo Square. Chicago: Lawrence Hill Books, 2009.

Tregle, Joseph G., Jr. “Early New Orleans Society: A Reappraisal.” Journal of Southern History 18 (February 1952): 21-36.

---. Louisiana in the Age of Jackson. A Clash of Cultures and Personalities. Baton Rouge: Louisiana State University Press, 1999.

Williams, Jack K. Dueling in the Old South. Vignettes of Social History. College Station and London: Texas A\&M University, 1980.

Woodward, C. Vann. The Burden of Southern History. 1960. Baton Rouge: Louisiana State University Press, 1970.

\section{NOTES}

1. Although the definition varied through time and place, in early American Louisiana, Creole meant born in Louisiana of French (or Spanish) ancestry. Reserved for white Louisianans, it was occasionally used to designate other categories but was then generally combined with further information on the origins of the people (Havana Creole, Saint-Domingue Creole, etc.). In later periods it was used to also designate free blacks of French ancestry (generally under the expression Creoles of color).

2. The territory purchased by the United States was large and presented various perspectives in terms of races and race relations. For the sake of consistency, this article will focus on Lower Louisiana, and more precisely on what became the state of Louisiana in 1812.

3. For a very comprehensive study of the development of slavery in French Louisiana, see Hall, chapters 1 to 8, more specifically 56-155.

4. See Hall 10.

5. Only one slave ship reached Louisiana in the last ten years of French rule. See Hall 11.

6. See Hall's chapter 9 entitled "Re-Africanization Under Spanish Rule", 275-315.

7. Hall 279.

8. See chapter entitled "Avenues of Freedom" in Hanger 17-54.

9. See tables I.I and 1.3 in Hanger, 18 and 22, respectively.

10. See the very comprehensive study by Hanger and more particularly chapter 2 on the economic position of the free people of color ("Work and Property Accumulation", 55-88), chapter 4 on their position within the militia ("A Privilege and Honor to Serve", 
109-135) and chapter 5 on their political and cultural role in late colonial New Orleans (“Cultural and Political Activities", 136-162).

11. Hanger conducted her study from censuses and notarial archives.

12. See the whole chapter on the privileges granted by militia membership.

13. See, for instance, the example of Mme Couvent in Dessens 2010, "Nouvelle-Orléans", 110.

14. See, for instance works by Phillips, Stampp or even C. Van Woodward in the bibliography. Including Louisiana within the South as an entity, without distinguishing it, led to an oversimplification of racial representations. Early $20^{\text {th }}$-century historians never seemed to question the image of a biracial South, where blacks were almost all slaves, discriminated against and oppressed by their white masters.

15. Or what historians also sometimes call the "master narrative." See, for instance, Kastor and Weil 5.

16. Joseph G. Tregle pioneered this historiographical revision with his 1952 article "Early New Orleans Society: A Reappraisal" published in the Journal of Southern History.

17. See, for instance, Gwendolyn Middlo Hall, Kimberly Hanger, Thomas Ingersoll, or Ned Sublette, to cite only a few of the historians of Louisiana who have highlighted Louisiana's distinctiveness.

18. See, for instance, Albert Fossier, Arnold Hirsh and Joseph Logsdon, Caryn Cossé Bell, Virginia Dominguez, Joseph Tregle, Rebecca Scott, or Paul Lachance.

19. In Race, Sex, and Social Order in Early New Orleans, for instance, Jennifer Spear develops the idea that, if racial codification was indeed altered whenever Louisiana changed hands, from French to Spanish to American, there was much more continuity in the practice of race relations than heretofore thought between the French, Spanish and American eras. A quote by Dan Usner, professor at Vanderbilt University, on the back cover of her book comments that there is still much to do although Spear manages to take "full advantage of tangible special circumstances [...] to replace stale assumptions about the Crescent City's peculiar society with fresh insights into its comparative importance in early American history".

20. What is here meant by "ethnicity "is what Kastor and Weil define, in their introduction, as "a more elusive term in the Americas [than race] that usually suggests a combination of culture, physical appearance, and distinct pasts. Following this definition, the Saint-Domingue refugees could thus be considered as an ethnic group different from the Louisiana Creoles but also from the migrants who came to Louisiana directly from metropolitan France (Kastor and Weil 5).

21. The Historic New Orleans Collection is a private New Orleans archive founded in 1966.

22. For more details about the itineraries of Boze and Ste-Gême and for details on sources, see Dessens 2008, 140.

23. The present article is part of a larger project that relies on Boze's correspondence to write a detailed chronicle of New Orleans in the decades that followed the Louisiana Purchase. The manuscript is currently being reviewed by the University of Florida Press.

24. This quote is excerpted from the letter written by Boze on 10 August 1818, contained in Folder 23 of MSS 100. From now on, the Folder number will be indicated in 
the body of the article with indication between brackets of the folder number followed by the date of the letter. Most letters were written over a long period of time, to avoid excessive mailing costs, Boze writing in the same letter, often called "Bulletin"(Newsletter), over a period that could go from a few weeks to a few months. This accounts for the presence of two dates, most of the time, indicating the beginning and end of the writing of the letter contained in the folder. For this specific reference, it would read as (F 23, 10/08/18). The letters were originally written in French, all translations are mine.

25. This word cannot be translated in politically correct English. Translating it as "slave" or "black" would, however, lose the racial prejudice included in the word "nègre", which is the reason why I decided to leave it in its original version, as agreed with the editor of my forthcoming book.

26. See, for instance, Williams 4-5.

27. The word used in French was "ménagère" and is generally translated as housekeeper. It referred to the women of color (often racially mixed) who were the lifelong mistresses or companions of white men, generally the mothers of their illegitimate children. Although mixed marriages were forbidden in $19^{\text {th }}$-century New Orleans, there are several examples of such mentions in Boze's letters. Most of the time, these marriages were contracted in foreign countries, including in France.

28. See, for instance, Hirsh and Logsdon 92; also see Lachance, in Hirsh and Logsdon 101-130.

29. This battle, that occurred in January 1815, after the signing of peace with England, unbeknownst to the Louisianans, was a landmark in New Orleans's early American history. For more details see, for instance, Remini 136-168.

30. The children had, by then, lost their mother and their father was obviously too far to serve as counsel.

31. On the concept of identity in early American Louisiana, see Kastor and Weil 8-11.

\section{ABSTRACTS}

This article examines the representation of the racial pattern and pattern of race relations in early American New Orleans. Starting with a historical and historiographical contextualization, the article shows that race relations were more complex than is usually depicted, partly because considerations based on other criteria than race were superimposed on the traditional categories. It concludes that there was not one way of representing races and race relations in the first decades of the postcolonial era, and suggests that these representations greatly varied from one group to another and did not necessarily correspond to the current representation based on the American/Creole dichotomy.

Cet article s'intéresse à la représentation du système de classification raciale et des relations interraciales à la Nouvelle-Orléans au début de la période américaine. Après un rappel historique et historiographique sur cette question, l'article s'attache à démontrer que ces questions sont 
beaucoup plus complexes qu'il n'y paraît, entre autres du fait que des considérations autres que raciales sont souvent venues se superposer aux catégorisations traditionnelles. Il suggère qu'il n'y avait pas, dans les premières décennies de la période postcoloniale, une seule façon de considérer les races et les relations interraciales et que ces représentations ne correspondaient pas nécessairement à la représentation courante fondée sur une dichotomie Américains/Créoles.

\section{INDEX}

Mots-clés: Nouvelle-Orléans, relations interraciales, historiographie, créoles, américains, réfugiés de Saint-Domingue

Keywords: Antebellum New Orleans, races, race relations, historiography, creoles, americans, Saint-Domingue refugees

\section{AUTHORS}

\section{NATHALIE DESSENS}

Professor of American History and Civilization

Université Toulouse 2 - Le Mirail

dessens@univ-tlse2.fr 